\title{
Detection of Salmonella spp. from chevon, mutton and its environment in retail meat shops in Anand city (Gujarat), India
}

\author{
P. P. Makwana, J. B. Nayak, M. N. Brahmbhatt and J. H. Chaudhary \\ Department of Veterinary Public Health and Epidemiology, Anand Veterinary College, Anand Agricultural University, \\ Anand, Gujarat, India. \\ Corresponding author: P.P. Makwana, e-mail: Paresh.makwana1989@gmail.com, JBN: jbn_anand@yahoo.com \\ MNB: mnbrahmbhatt2003@yahoo.com,JHC: jitvph007@gmail.com \\ Received: 18-11-2014, Revised: 01-02-2015, Accepted: 10-02-2015, Published online: 23-03-2015
}

doi: 10.14202/vetworld.2015.388-392. How to cite this article: Makwana PP, Nayak JB, Brahmbhatt MN, Chaudhary JH (2015) Detection of Salmonella spp. from chevon, mutton and its environment in retail meat shops in Anand city (Gujarat), India, Veterinary World 8(3): 388-392.

\begin{abstract}
Aim: The aim of this study was (i) To attempt isolation and identification of Salmonella species from samples. (ii) Serotyping of Salmonella isolates. (iii) Detection of virulence factor associated genes by polymerase chain reaction (PCR).

Materials and Methods: A total of 284 samples comprised of chevon and mutton (112 samples each) as well as 60 samples (20 each of retail meat shops environment samples viz. Butchers' hands, knives and log swabs) were collected from the retail meat shops in and around Anand City under aseptic precautions. Rappaport-vassiliadis soy bean meal broth and tetrathionate broth was used for the enrichment of all the samples and inoculation was done on brilliant green agar and xylose lysine deoxycholate agar. This was followed by the confirmation of isolates using biochemical tests. For the serotyping, isolates were sent to the National Salmonella and Escherichia Centre, Central Research Institute, Kasauli, Himachal Pradesh. Detection of virulence genes was performed by PCR technique using previously reported primer.

Result: Of 284 meats and retail meat shops environment samples, $13(4.58 \%)$ samples were found positive for Salmonella. It was interesting to know that incidence of Salmonella was more in mutton (6.25\%) than chevon (3.57\%). In case of meat shop environmental samples $1(5.00 \%)$ sample observed positive for Salmonella separately among the butchers' hands and knives swabs (Each of 20 samples) examined. Out of 13, eleven isolates detected as Salmonella Typhimurium, whereas only two isolates were detected as Salmonella Enteritidis. All Salmonella isolates possess invA and stn genes, whereas nine isolates had a presence of $s p v \mathrm{R}$ gene while only five of the isolates revealed the presence of $s p v \mathrm{C}$ gene as shown by in vitro detection of virulence genes by PCR.
\end{abstract}

Conclusion: Therefore, might be suggested that the good hygiene practices and effective control measures should be taken to encourage clean meat production with prolonged shelf-life.

Keywords: food safety, meat, prevalence, Salmonella spp, serotype.

\section{Introduction}

Population growth has increased the requirements for an expanded food industry production [1]. In these industry production, Salmonella remains in first place of world's leading causes of bacterial food borne illness [2]. The first outbreak of salmonellosis reported during the late 1800's in which 57 people affected that ate beef. Due to Salmonella infections 93.8 million cases of gastroenteritis reported in year worldwide, with 155,000 deaths. Milder infections of Salmonella are mostly under-diagnosed; therefore the actual cases of infections may be very high [3]. The financial losses occurred due to Salmonella infections have drawn increasing attention in developed countries in recent years.

Animals are exposed to Salmonella in many ways (i.e. water, feed, feces, soil, and insects) and can become infected or asymptomatic carriers of the Salmonella organism [3]. People become infected with Salmonella by contaminated food and water.

Copyright: The authors. This article is an open access article licensed under the terms of the Creative Commons Attributin License (http:// creative commons.org/licenses/by/2.0) which permits unrestricted use, distribution and reproduction in any medium, provided the work is properly cited.
Salmonella infection primarily spread from contaminated areas by human and Animals activities to other animals and areas.

Chevon and mutton are valuable source of protein and it is frequently consumed by many communities in India, specifically at religious event celebration. Goats and sheep are mostly slaughtered at small abattoirs having not so much hygienic conditions in most parts of India [4]. The poor hygienic conditions in the slaughterhouses and meat shops encourage microbial contamination, survival and growth [5].

Thus, the aim of this study was to detection of Salmonella spp. from chevon, mutton and its environment in retail meat shops.

\section{Materials and Methods}

\section{Ethical approval}

All the procedures have been carried out in accordance with the guidelines laid down by the Institutional Ethics Committee and in accordance with local laws and regulations.

\section{Sample collection}

From July 2013 to March 2014, a total of 284 samples comprised of chevon and mutton (112 samples 
each) were excised with a sterile scalpel under aseptic conditions into sterilized polythene bags from the retail meat shops in and around Anand city. Each bag was labeled indicating code number and other particulars of the sample. Moreover, 60 samples (20 each of retail meat shops environment samples viz. Butchers' hands, knives and log swabs) were taken into cairy blair transport medium and placed in thermocol box containing ice and brought to the departmental post-graduate laboratory for further processing and microbiological analysis.

\section{Isolation and identification}

Samples were processed as per standard protocol described in bacteriological analytical manual (BAM), U.S. Food and Drug Administration (USFDA) method [6] with necessary modifications.

a) Chevon and mutton: $25 \mathrm{~g}$ of the meat sample will be homogenized with $225 \mathrm{ml}$ of lactose broth in a stomacher blender and pre-enriched at $37^{\circ} \mathrm{C}$ for $24 \mathrm{~h}$., approximately 0.1 and $1 \mathrm{ml}$ of pre-enriched samples are transferred to rappaport-vassiliadis soy bean meal broth and tetrathionate broth, respectively, followed by $24 \mathrm{~h}$ of incubation at 42 and $37^{\circ} \mathrm{C}$, respectively. The enrichments are streaked on brilliant green agar and xylose lysine deoxycholate agar and incubated for $24 \mathrm{~h}$ at $35^{\circ} \mathrm{C}$. All presumptive Salmonella colonies will be inoculated on triple sugar iron (TSI) agar and incubated at $37^{\circ} \mathrm{C}$ for $24 \mathrm{~h}$ and further biochemical characterization of the isolates will be carried out Figure-1.

b) Retail meat shop environment samples: Swab collected from butchers' hands, knives and log will be directly inoculated in pre-enrichment broth and further processed in a similar manner as mentioned above.

\section{Biochemical examination}

Biochemical tests were performed to confirm Salmonella Spp. Using catalase test, oxidase test, indole test, citrate test, urease test, voges proskaur (VP) test and $\mathrm{H}_{2} \mathrm{~S}$ production TSI (Table-1).

Serotyping of Salmonella isolates: Salmonella isolated from samples were serotyped at the National Salmonella and Escherichia Centre, Central Research Institute, Kasauli, H. P., India.

DNA isolation: Extraction of DNA from Salmonella was done by using boiling method [7].

Table-1: Biochemical characteristics of Salmonella.

\begin{tabular}{lc}
\hline Test & Reaction \\
\hline Catalase & + \\
Oxidase & - \\
$\mathrm{H}_{2}$ S production (TSI) & + \\
Indole test & - \\
MR test & + \\
VP test & - \\
Citrate test & + \\
Urease test & - \\
\hline
\end{tabular}

TSI=Triple sugar iron, $\mathrm{MR}=$ methyl red, $\mathrm{VP}=$ voges proskaur
Approximately a loopful of culture was taken in a micro centrifuge tube and mixed with $100 \mu 1$ of sterilized DNAse and RNAse free water. This was followed by denaturation at $95^{\circ} \mathrm{C}$ for $10 \mathrm{~min}$ using the thermal cycler (Applied Biosystems, Sweden). Finally, cell debris was removed by centrifugation (10000 rpm for $5 \mathrm{~min}$ ) and $3 \mu \mathrm{l}$ of the supernatant was used in the PCR as DNA-template.

\section{Detection of virulence genes by polymerase chain reaction}

All the Salmonella isolates were first screened for the presence or absence of virulence associated genes by using the PCR protocols separately standardized for the detection of different genes. The PCR was standardized for the detection of four genes viz. invA, $s p v \mathrm{R}, s p v \mathrm{C}$ and $s t n$ following the methodology as described by [8-11] respectively, with suitable modifications. Standardization of PCR was done by using standard strain of Salmonella Typhimurium (VP81) (Table-2).

\section{Results and Discussion}

\section{Prevalence of Salmonella spp.}

In the present study, it was revealed that, out of 284 samples comprised of chevon and mutton (112 samples each) as well as 60 samples (20 each of retail meat shops environment samples viz. Butchers' hands, knives and log swabs), 13 (4.58\%) samples were found positive for Salmonella spp. (Table-3) according to cultural characteristics and biochemical tests (Table-1). The occurrence of Salmonella was more in mutton $(6.25 \%)$ than chevon $(3.57 \%)$. Finding of the present study was in concordance with Kumar et al. [12] and very low than the previously reported more than $5.0 \%$ prevalence [13].

\section{Serotyping of Salmonella isolates}

There were eleven isolates detected as $S$. Typhimurium, while two isolates were detected as Salmonella Enteritidis. Serotype of individual isolate is shown in Table-4. This result correlates well with Selvaraj et al. [14] who reported $S$. Typhimurium and $S$. Enteritidis as the predominant serovars in India from different animal sources. Whereas other authors reported various other serotypes like Salmonella Infantis Yadav et al. [15], Salmonella Saintpaul and Salmonella Chester [16], Salmonella Kissi [17].

\section{Detection of virulence gene by PCR}

Out of 13 Salmonella isolates all yielded desired amplified products of $284 \mathrm{bp}$ and $260 \mathrm{bp}$ for invA and stn genes, respectively as shown in Figures-2 and 3 similar results have also been reported by Mir et al. [18] and Singh et al. [19].

Whereas, nine of the isolates produced $310 \mathrm{bp}$ product specific for $s p v$ R (Figure-4). In contrast to our results Oliveira et al. [10] found that $91.20 \%$ Salmonella Enteritidis isolates contained the $s p v \mathrm{R}$ gene. Bessa et al. [20] reported that out of 66 


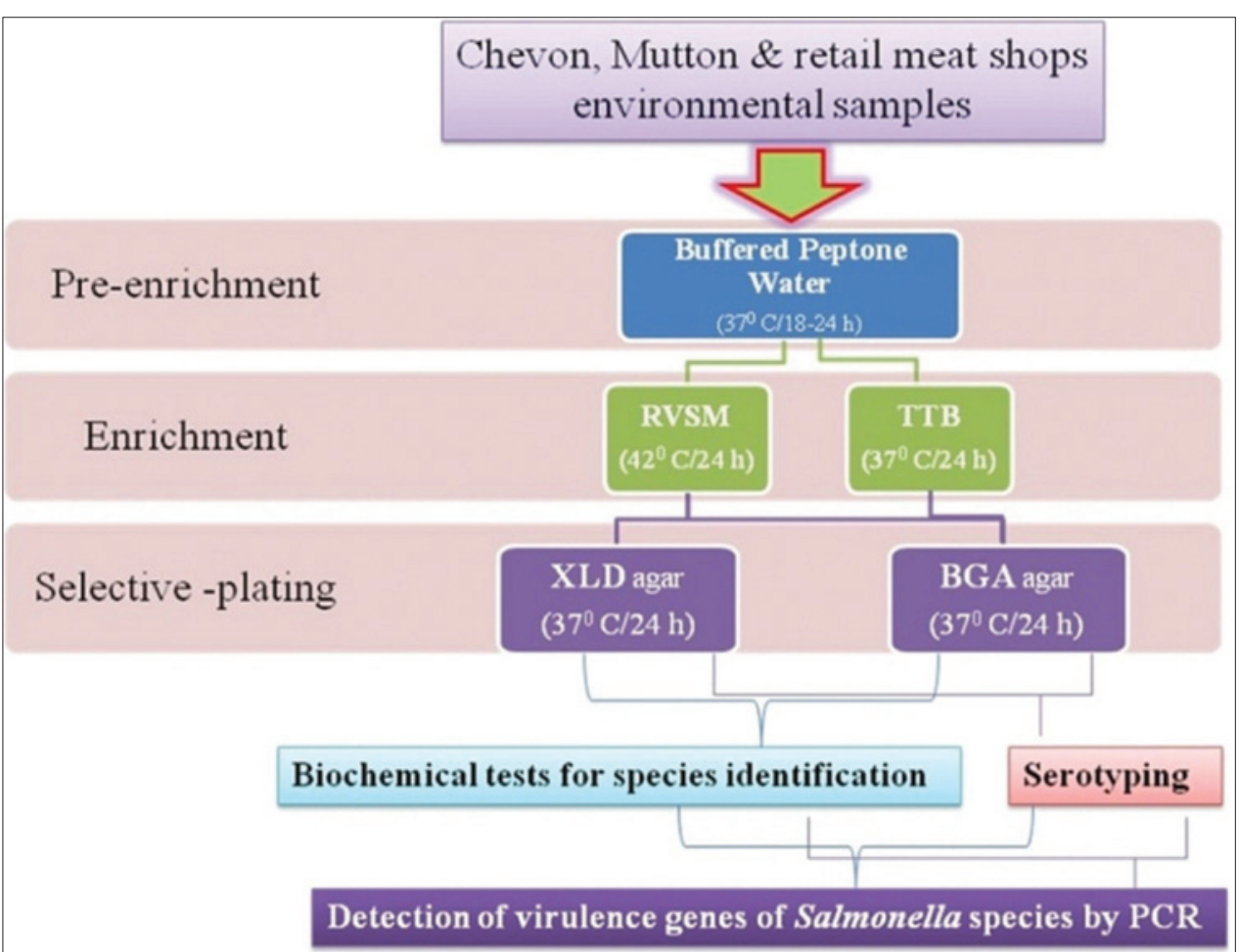

Figure-1: Procedure for isolation of Salmonella from chevon, mutton and retail meat shops environmental samples.

Table-2: Primer pairs used for virulence associated genes characterization of Salmonella isolates.

\begin{tabular}{|c|c|c|c|c|}
\hline Target genes & Primer sequence $\left(5^{\prime} \rightarrow 3^{\prime}\right)$ & Product size (bp) & Reference accession no & References \\
\hline invA & $\begin{array}{l}\text { F: GTG AAA TTA TCG CCA CGT TCG GGC AA } \\
\text { R: }\end{array}$ & 284 & AE 006468.1 & 7 \\
\hline$s p v R$ & $\begin{array}{l}\text { F: CAG GTT CCT TCA GTA TCG CA } \\
\text { R: TIT GGC CGG AAA TGG TCA GT }\end{array}$ & 310 & AE 006471.1 & 8 \\
\hline$s p v C$ & $\begin{array}{l}\text { F: ACT CCT TGC ACA ACC AAA TGC GGA } \\
\text { R: TGT CTT CTG CAT TTC GCC ACC ATC A }\end{array}$ & 571 & AE 006471.1 & 9 \\
\hline Stn & $\begin{array}{l}\text { F: CTT TGG TCG TAA AAT AAG GCG } \\
\text { R: TGC CCA AAG CAG AGA GAT TC }\end{array}$ & 260 & AE 006468.1 & 10 \\
\hline
\end{tabular}

$\mathrm{F}=$ Forward primer, $\mathrm{R}=$ Reverse primer

Table-3: Source wise prevalence of Salmonella spp.

\begin{tabular}{|c|c|c|c|c|c|c|}
\hline \multirow{2}{*}{$\begin{array}{l}\text { Source of } \\
\text { samples }\end{array}$} & \multicolumn{2}{|c|}{ Meat samples } & \multicolumn{3}{|c|}{ Environmental swab samples } & \multirow{2}{*}{$\begin{array}{c}\text { Total no of } \\
\text { positive sample }\end{array}$} \\
\hline & Chevon & Mutton & Butchers' hands & Knives & Log & \\
\hline Shop 1 & $1(3.57)$ & $1(3.57)$ & $1(20.00)$ & ND & ND & $3(4.22)$ \\
\hline Shop 2 & $1(3.57)$ & $3(10.71)$ & ND & ND & ND & $4(5.63)$ \\
\hline Shop 3 & $2(7.14)$ & $1(3.57)$ & ND & $1(20.00)$ & ND & $4(5.63)$ \\
\hline Shop 4 & ND & $2(7.14)$ & ND & ND & ND & $2(2.82)$ \\
\hline Total & $4(3.57)$ & $7(6.25)$ & $1(5.00)$ & $1(5.00)$ & ND & $13(4.58)$ \\
\hline
\end{tabular}

Note: Figures in parenthesis indicate percentage, ND=Not detected

Salmonella Typhimurium strains $4.54 \%$ positive for $s p v \mathrm{R}$ by PCR assay.

While only five isolates of Salmonella yielded $571 \mathrm{bp}$ product specific for $s p v \mathrm{C}$ gene (Figure-5) which correlate well with Das et al. [21] who reported that $42.85 \%$ isolates yielded $s p v \mathrm{C}$ gene from 35 S. enterica isolates by PCR assay.

\section{Conclusion}

Different serotypes isolated from these environmental sources, majority of these serotypes were of zoonotic significance and thus, these places require appropriate hygiene to avoid cross contamination of the meat. A thorough sanitation procedure not only prevents potential hazard to human health but also creates the clean surroundings.

Data profiles of this study also use for establish direction and help to evaluate control strategy of meatborne disease related to Salmonella bacteria.

\section{Authors' Contributions}

PPM supervised the overall research work. PPM and JHC participated in analysis of samples and made available relevant literatures. JBN and 


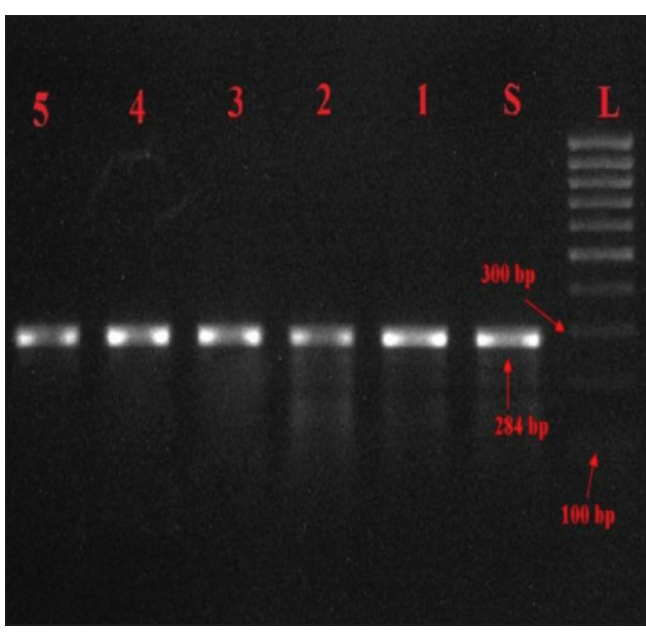

Figure-2: Agarose gel showing PCR amplified products (284bp) for invA gene in Salmonella isolates

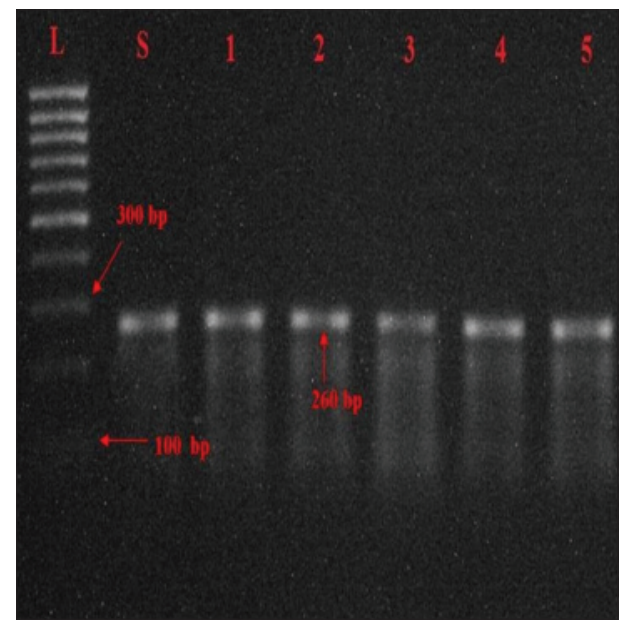

Figure-3: Agarose gel showing PCR amplified products (260bp) for stn gene in Salmonella isolates

Table-4: Isolate wise serotype and prevalence of virulence genes.

\begin{tabular}{llcccc}
\hline Isolate & Serotype & \multicolumn{5}{c}{ Virulence gene } \\
\cline { 3 - 6 } & & invA & spvR & spvC & Stn \\
\hline C1-09 & Typhimurium & + & + & + & + \\
C2-17 & Typhimurium & + & - & + & + \\
C3-25 & Typhimurium & + & + & - & + \\
C3-02 & Typhimurium & + & + & - & + \\
M1-05 & Typhimurium & + & + & - & + \\
M2-03 & Typhimurium & + & + & - & + \\
M2-07 & Enteritidis & + & - & - & + \\
M2-23 & Typhimurium & + & + & & + \\
M3-11 & Typhimurium & + & - & - & + \\
M4-08 & Typhimurium & + & + & + & + \\
M4-27 & Enteritidis & + & + & - & + \\
BH1-05 & Typhimurium & + & - & + & + \\
K3-02 & Typhimurium & + & + & - & + \\
\hline & & & & &
\end{tabular}

MNB participated in draft and revision of the manuscript. All authors read and approved the final manuscript.

\section{Acknowledgements}

The authors are grateful to the Department of Veterinary Public Health, Anand Agricultural

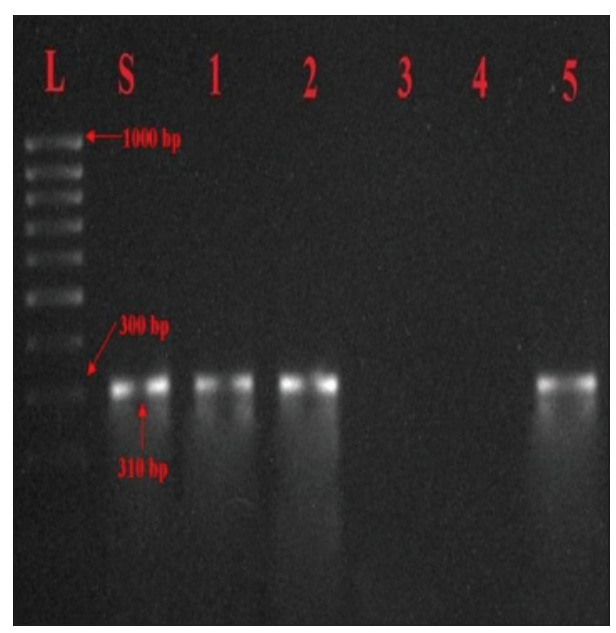

Figure-4: Agarose gel showing PCR amplified products (310bp) for spvR gene in Salmonella isolates

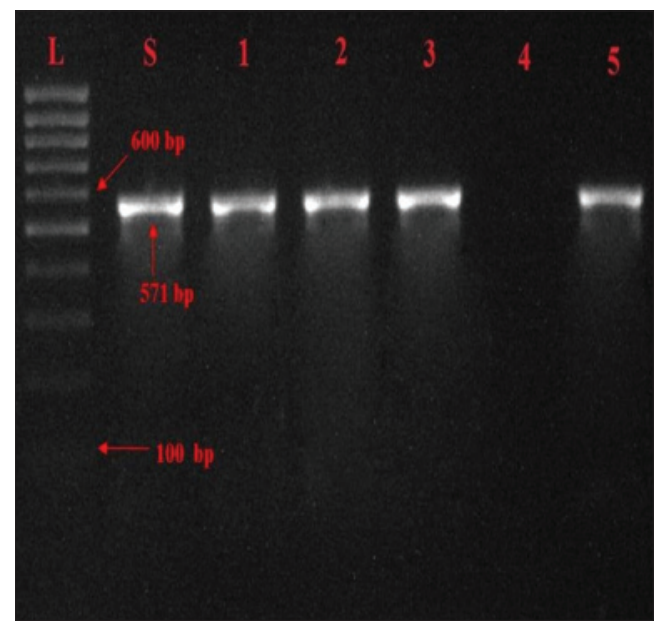

Figure-5: Agarose gel showing PCR amplified products (571bp) for spvC gene in Salmonella isolates

University for providing financial support to the present investigation.

\section{Competing Interests} interests.

The authors declare that they have no competing

\section{References}

1. Hanning, I.B., Ricke, S.C. and Nutt, J.D. (2009) Salmonellosis outbreaks in the United States due to fresh produce: Sources and potential intervention measures. Foodborne Pathog. Dis., 6(6): 635-648.

2. Wolffs, P.F.G., Glencross, K., Thibaudeau. R. and Griffiths, M.W. (2006) Direct quantitation and detection of Salmonella in biological samples without enrichment, using two-step filtration and real-time PCR. Appl. Environ. Microbiol. 72: 3896-3900.

3. Jay, J.M. (1996) Modern Food Microbiology. 5th ed. Chapman and Hall, New York. p661.

4. Chandra, M., Singh, B.R., Shankar, H., Agarwal, M., Agarwal, R., Sharma, G. and Babu, N. (2006) Study on prevalence of Salmonella infection in goats. Small Rumin. Res., 65: 24-30.

5. Bhandare, S.G., Sherikar, A.T., Paturkar, A.M., Waskar, V.S. and Zende, R.J. (2007) A comparison of microbial contamination on sheep/goat carcasses in a modern Indian abattoir and traditional meat shops. Food Control, 18: 854-858. 
6. Andrews, W.H., Andrew J. and Hammack, T. (2011) Salmonella. In: Bacteriological Analytical Manual. 8th ed., Revision A, Ch. 5. U.S. Food and Drug Administration, AOAC International, Gaithersburg, MD.

7. Beverley, C., Millar, X.J., John, E.M. and John A.P.E. (2000) A simple and sensitive method to extract bacterial, yeast and fungal DNA from blood culture material. $J$. Microbiol. Methods, 42(2): 139-147.

8. Kumar, K., Saklaini, A.C., Singh, S. and Singh, V.P. (2008) Evaluation of specificity for invA gene PCR for detection of Salmonella spp. Proceeding of VII ${ }^{\text {th }}$ Annual Conference of Indian Association of Veterinary Public Health Specialists (IAVPHS) (November 07-09, 2008).

9. Pasmans, F., Van Immerseel, F., Heyndrickx, M., Godard, C., Wildemauwe, C., Ducatelle, R. and Haesebrouck, F. (2003). Host adaptation of pigeon isolates of Salmonella serovar Typhimurium var. Copenhagen PT99 is associated with macrophage cytotoxicity. Infect. Immunol., 71: 6068-6074.

10. Oliveira, S.D., Rodenbusch, C.R., Michae, G.B., Cardoso, M.I.R., Canal, C.W. and Brandelli, A. (2003) Detection of virulence genes in Salmonella enteritidis isolated from different sources. Braz. J. Microbiol., 34(1): 123-124.

11. Makino, S., Kurazono, H., Chongsanguam, M., Hayashi, H., Cheun, H., Suzuki, S. and Shirahata, T. (1999) Establishment of the PCR system specific to Salmonella spp. and its application for the inspection of food and fecal samples. J. Vet. Med. Sci., 61(11): 1245-1247.

12. Kumar, A., Khajuria, P. and Kaur, M. (2011) Tracking of pathogenic and spoilage microbes in mutton and chevon processing in retail markets of Jammu. Indian. J. Small Rumin., 17(1): 74-78.

13. Bachhil, V.N. and Jaiswal, T.N. (1988) Occurrence of
Salmonella in meats. J. Food Sci. Technol., 25: 310-312.

14. Selvaraj, R., Das, R., Ganguly, S., Ganguli, M., Dhanalakshmi, S. and Mukhopadhayay, S.K. (2010) Characterization and antibiogram of Salmonella spp. from poultry specimens. J. Microbiol. Antimicrob., 2: 123-126.

15. Yadav, M.M., Tale, S., Sharda, R., Sharma, V., Tiwari, S. and Garg, U.K. (2006) Bacteriological quality of sheep meat in Mhow town of India. Int. J. Food Sci. Technol., 41: 1234-1238.

16. Duffy, L., Barlow, R., Fegan, N. and Vanderlinde, P. (2009) Prevalence and serotypes of Salmonella associated with goats at two Australian abattoirs. Lett. Appl. Microbiol., 48: 193-197.

17. Lambey, H.S., Verma, A.K., Jain, U., Mahima., and Bist, B. (2009) Bacteriological quality of chevon and pork in Mathura City. J. Vet. Public Health, 7(2): 141-143.

18. Mir, I.A., Wani, S.A., Hussain, I., Qureshi, S.D. and Bhat, M.A. (2010) Molecular epidemiology and in vitro antimicrobial susceptibility of Salmonella isolated from poultry in Kashmir. Rev. Sci. Tech. Office Int. Epizoot., 29(3): 677-686.

19. Singh, S., Singh, H., Tewari, S.C., Prejit, N. and Agarwal, R.K. (2013) Characterization of virulence factors among diverse Salmonella serotypes and sources. Adv. Anim. Vet. Sci., 1(2): 69-74.

20. Bessa, M.C., Michael, G.B., Canu, N., Canal, C.W., Cardoso, M., Rabsch, W. and Rubino, S. (2007) Phenotypic and genetic characterization of Salmonella enterica subsp. enterica serovar Typhimurium isolated from pigs in Rio Grande do Sul, Brazil. Res. Vet. Sci. 83: 302-310.

21. Das, A., Hari, S.S., Shalini, U., Ganeshkumar, A. and Karthikeyan, M. (2012) Molecular screening of virulence genes from Salmonella enterica isolated from commercial food stuffs. Biosci. Biotechnol. Res. Asia, 9(1): 363-369. 